\title{
AI NLP Chatbot for HR and Employee Support
}

\author{
C.Anuradha, N.Priya, S. Sangeetha, G.Kavitha
}

\begin{abstract}
This task is planned for building up an online chatbot for leave the executives framework that is of significance to either an association. The Leave Management System (LMS) is an Intranet based application that can be gotten to all through the association or a predefined gathering/Dept. In this,we utilized Natural Language Processing(NLP) which is a part of Artificial Intelligence(AI). With NLP[1] the cooperation among $P C$ and people are possible.This framework can be utilized to mechanize the work process of leave applications and their endorsements. The occasional crediting of leave is additionally automated.There are highlights like email notices, programmed endorsement of leave, report generators and so on in this framework. Leave Management application will lessen administrative work and keeps up record in progressively proficient manner. This framework will redesign the procedure of leave the board inside organization by sparing time and assets. The Leave Management System serves to workers can view leave adjusts, demand leaves, see past leave history and chief can affirm leave applications. The talk bot will give every one of the reactions what the client inquired.
\end{abstract}

Keywords : Chatbot, Natural Language Processing(NLP)

\section{INTRODUCTION}

AI NLP Chat bot for Leave Management System is a web based system which can be accessed all over the organization or company.[1] With this Chabot, the employees can interact with the artificial bot and can get responses regarding their requests.[2] First, we will feed the bot with the intents and respective responses. After, with the NLP model chatbot is trained well[3]. Now, we will get the data in JSON [2]format. We will copy the access token and paste it in the interface in order to display it on screen [4].This system is automated system for managing leaves related information of employees and approval of leaves[5]. Every employee is provided with unique id and password for login to the system and send request for leave. Project manager of higher authorities will look after the proposal and they may accept ,reject or keep it in pending[6]. This system will upgrade the process of leave management inside company by saving time and resources.It helps to employees can view leave balances, request leaves, view past leave history and manager can approve leave applications. This system manages different leave types like maternity leave, sick leave and optional leave[7]. This system used to automate the work flow of leave applications and

Revised Manuscript Received on July 22, 2019.

C.Anuradha, Department of Comuter Science and Engineering, Bharath Institute of Higher Education and Research, Chennai. Email: anuradha.ak23@gmail.com

N.Priya, Department of Computer Science and Engineering, Bharath Institute of Higher Education and Research, Chennai. Email: priyabiher@gmail.com

S. Sangeetha, Department of Computer Science and Engineering, Bharath Institute of Higher Education and Research, Chennai. Email: sangeethasathya01@gmail.com

G.Kavitha, Department of Computer Science and Engineering, Bharath Institute of Higher Education and Research, Chennai. Email: kavithag90@gmail.com their approvals in corporate world[8] This system have many features such as notification of email, leave cancellation ,automated leave approval. This system is web based system used to track and manage employees leave, absence details. This system also automatically deduct the leaves taken from available leaves.[9][10][11]

\section{EXISTING SYSTEM}

- In Leave Management System, all the employees can login through the website and apply for the leave.

- Manager will approveldeny the leave based on the leave history of the employee and will give comments on that $[12][13]$.

- Leave History will be showed for all the employees and pending leaves will be maintained. Manager will approve them. [15][16]

\section{PROPOSED SYSTEM}

- In Proposed System, the escalation will be there. The pending leaves will be shown in red colour, such that manager has to approve the leave immediately.

- We used AI Chatbot here in this application using Dialog Flow and Natural Language Processing(NLP)16].

- Push notifications via mail will be sent to respected manager whenever the employee applied for the leave.[39]

- Filter and sort pipes are used here for sorting and searching of employees from the database. Employee pictures and all the details are maintained and shown on the application.

- This shows that the employee has a manager or not. If manager is not there means histher leave will be approved automatically.

Different type of leaves can be applied like Maternal, Earned and Sick leaves[18]. All are categorized into separate and has their own no of allotted days for leave.

\section{MODULE DESCRIPTION}

In this section the modules of the leave management system are described. The leave management system is divided into two modules.[19]

List of Modules:

a) Chatbot

b) Manager

c) Employee

A. CHATBOT

a) This module consists of many specifications like:

b) i. Dialog Flow

c) Description

d) In Dialog Flow we will the bot with the user expressions and give responses according to the expressions. 


\section{B. MANAGER}

This module consists of many specifications like:

\section{Dashboard}

In Dashboard, manager can view his project mates and can approve or deny their leaves.Here, manager has to login with his allotted employee id and password.[20]

Functional Requirements:

The system must allow the manager to see employee details, leave history and leave details.

\section{Leave History}

Here the manager can view his leave history. The manager can apply for leaves and his leaves are auto-approval.[21] Functional Requirements:

Clicking on history will display the employee leave history. By going through the leave history of employees, manager can approve or deny the leaves. [22]

\section{Approve/Deny}

Here the Manager will approve or reject the applied leaves by the employees. Here we provided[26] an extra feature for re-approval and re-deny.

\section{EMPLOYEE}

Employee can login through the system with his/her user Id and password. After successful login to the application employee navigates to the Dashboard. Where Employee details are available with the respective manager[27] details. If the Employee has no manager, it will display as "No Manager".

\section{Apply Leave}

Here Employee can apply for the leave by providing all the information in the form of apply leave.[28]

Functional Requirements:

Application must be able to verify information

Applicationmust be able to re-ask for the missed details of the employee.[29]

\section{Leave History}

Here the manager can view his leave history. The manager can apply for leaves and his leaves are auto-approval in Figure:1.

Functional Requirements:

Application must be able to search the database based on select search type and retrieve the leave history[8].

Application must be able to filter the leave details and sort it according the latest applied leaves.[30]

\section{Login $\backslash$ Log out}

This component is utilized by the client to login into framework. They are required to enter client id and secret phrase before they access to the site. The client id and secret key will be confirmed and on the off chance that the client id and secret word are invalid, at that point the clients won't almost certainly get to their library accounts.[31]

Practical necessities:

Client id is given when they register.

The framework must permit client with legitimate id and secret word to enter the system.[32]

Framework performs approval process which chooses what client level can access[33]

The client must almost certainly logout after they got done with utilizing framework.

\section{Employee Search}

Here the Employee can search for his her Employee details.

Functional requirements:

This system must provide efficient searching for the Employees.[34]

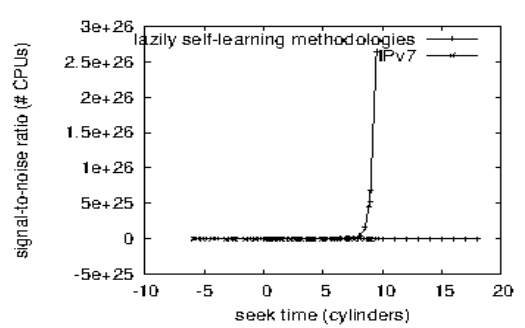

Figure 1: These results were obtained by Matt Welsh

\section{III.CONCLUSION}

With this online ChatBot for Leave Management System, employees can get their queries resolved easily and can get help how toapply their leaves online.With the mail service the manager get notification about the employee leave and with the escalation the manager will get to know that the leave should be approved immediately. The manager can re-approve the leave after denying the leave. The employee can edit histher leave and can edit their passwords. In the apply leave module, the application is made in such a way that, the leave balance will not deduct the weekends from the available leaves. And on optional holidays employee can not apply for leaves. Leave History is maintained and all the employee pending leaves or approved leaves will be shown on the GUI[9].

\section{REFERENCES}

[1] G Kumaravel A., Rangarajan K.,Algorithm for automaton specification for exploring dynamic labyrinths,Indian Journal of Science and Technology,V-6,I-SUPPL5,PP-4554-4559,Y-2013

[2] P. Kavitha, S. Prabakaran "A Novel Hybrid Segmentation Method with Particle Swarm Optimization and Fuzzy C-Mean Based On Partitioning the Image for Detecting Lung Cancer" International Journal of Engineering and Advanced Technology (IJEAT) ISSN: 2249-8958, Volume-8 Issue-5, June 2019

[3] Kumaravel A., Meetei O.N.,An application of non-uniform cellular automata for efficient cryptography,2013 IEEE Conference on Information and Communication Technologies, ICT 2013,V-,I-,PP-1200-1205,Y-2013

[4] Kumarave A., Rangarajan K.,Routing alogrithm over semi-regular tessellations,2013 IEEE Conference on Information and Communication Technologies, ICT 2013,V-,I-,PP-1180-1184,Y-2013

[5] P. Kavitha, S. Prabakaran "Designing a Feature Vector for Statistical Texture Analysis of Brain Tumor" International Journal of Engineering and Advanced Technology (IJEAT) ISSN: 2249-8958, Volume-8 Issue-5, June 2019

[6] Dutta P., Kumaravel A.,A novel approach to trust based identification of leaders in social networks,Indian Journal of Science and Technology,V-9,I-10,PP--,Y-2016

[7] Kumaravel A., Dutta P.,Application of Pca for context selection for collaborative filtering,Middle - East Journal of Scientific Research,V-20,I-1,PP-88-93,Y-2014

[8] Kumaravel A., Rangarajan K.,Constructing an automaton for exploring dynamic labyrinths,2012 International Conference on Radar, Communication and Computing, ICRCC 
2012,V-,I-,PP-161-165,Y-2012

[9] P. Kavitha, S. Prabakaran "Adaptive Bilateral Filter for Multi-Resolution in Brain Tumor Recognition" International Journal of Innovative Technology and Exploring Engineering (IJTTEE) ISSN: 2278-3075, Volume-8 Issue-8 June, 2019

[10] Kumaravel A.,Comparison of two multi-classification approaches for detecting network attacks, World Applied Sciences Journal,V-27,I-11,PP-1461-1465,Y-2013

[11] Tariq J., Kumaravel A.,Construction of cellular automata over hexagonal and triangular tessellations for path planning of multi-robots,2016 IEEE International Conference on Computational Intelligence and Computing Research, ICCIC 2016,V-,I-,PP--,Y-2017

[12] Sudha M., Kumaravel A.,Analysis and measurement of wave guides using poisson method,Indonesian Journal of Electrical Engineering and Computer Science, V-8,I-2,PP-546-548,Y-2017

[13] Ayyappan G., Nalini C., Kumaravel A.,Various approaches of knowledge transfer in academic social network,International Journal of Engineering and Technology,V-,I-,PP-2791-2794,Y-2017

[14] Kaliyamurthie, K.P., Sivaraman, K., Ramesh, S. Imposing patient data privacy in wireless medical sensor networks through homomorphic cryptosystems 2016, Journal of Chemical and Pharmaceutical Sciences92.

[15] Kaliyamurthie, K.P., Balasubramanian, P.C. An approach to multi secure to historical malformed documents using integer ripple transfiguration 2016 Journal of Chemical and Pharmaceutical Sciences92.

[16] A.Sangeetha,C.Nalini,"Semantic Ranking based on keywords extractions in the web", International Journal of Engineering \& Technology, 7 (2.6) (2018) 290-292

[17] S.V.GayathiriDevi,C.Nalini,N.Kumar,"An efficient software verification using multi-layered software verification tool "International Journal of Engineering \& Technology, 7(2.21)2018 454-457

[18] C.Nalini,ShwtambariKharabe,"A Comparative Study On Differen Techniques Used For Finger - Vein Authentication", International Journal Of Pure And Applied Mathematics, Volume 116 No. 82017 , 327-333, Issn: 1314-3395

[19] M.S. Vivekanandan and Dr. C. Rajabhushanam, "Enabling Privacy Protection and Content Assurance in Geo-Social Networks", International Journal of Innovative Research in Management, Engineering and Technology, Vol 3, Issue 4, pp. 49-55, April 2018.

[20] Dr. C. Rajabhushanam, V. Karthik, and G. Vivek, "Elasticity in Cloud Computing", International Journal of Innovative Research in Management, Engineering and Technology, Vol 3, Issue 4, pp. 104-111, April 2018.

[21] K. Rangaswamy and Dr. C. Rajabhushanamc, "CCN-Based Congestion Control Mechanism In Dynamic Networks", International Journal of Innovative Research in Management, Engineering and Technology, Vol 3, Issue 4, pp. 117-119, April 2018.

[22] Kavitha, R., Nedunchelian, R., "Domain-specific Search engine optimization using healthcare ontology and a neural network backpropagation approach", 2017, Research Journal of Biotechnology, Special Issue 2:157-166

[23] Kavitha, G., Kavitha, R., "An analysis to improve throughput of high-power hubs in mobile ad hoc network" , 2016, Journal of Chemical and Pharmaceutical Sciences, Vol-9, Issue-2: 361-363

[24] Kavitha, G., Kavitha, R., "Dipping interference to supplement throughput in MANET", 2016, Journal of Chemical and Pharmaceutical Sciences, Vol-9, Issue-2: 357-360

[25] Michael, G., Chandrasekar, A.,'Leader election based malicious detection and response system in MANET using mechanism design approach", Journal of Chemical and Pharmaceutical Sciences(JCPS) Volume 9 Issue 2, April - June 2016

[26] Michael, G., Chandrasekar, A.,"Modeling of detection of camouflaging worm using epidemic dynamic model and power spectral density", Journal of Chemical and Pharmaceutical Sciences(JCPS) Volume 9 Issue 2, April - June 2016

[27] Pothumani, S., Sriram, M., Sridhar, J., Arul Selvan, G., Secure mobile agents communication on intranet,Journal of Chemical and Pharmaceutical Sciences, volume 9, Issue 3, Pg No S32-S35, 2016

[28] Pothumani, S., Sriram, M., Sridhar, Various schemes for database encryption-a survey, Journal of Chemical and Pharmaceutical Sciences, volume 9, Issue 3, Pg NoS103-S106, 2016
[29] Pothumani, S., Sriram, M., Sridhar, A novel economic framework for cloud and grid computing, Journal of Chemical and Pharmaceutical Sciences, volume 9, Issue 3, Pg No S29-S31, 2016

[30] Priya, N., Sridhar, J., Sriram, M. "Ecommerce Transaction Security Challenges and Prevention Methods- New Approach” 2016 ,Journal of Chemical and Pharmaceutical Sciences, JCPS Volume 9 Issue 3.page no:S66-S68

[31] Priya, N.,Sridhar,J.,Sriram, M."Vehicular cloud computing security issues and solutions" Journal of Chemical and Pharmaceutical Sciences(JCPS) Volume 9 Issue 2, April - June 2016

[32] Priya, N., Sridhar, J., Sriram, M. "Mobile large data storage security in cloud computing environment-a new approach" JCPS Volume 9 Issue 2. April - June 2016

[33] Anuradha.C, Khanna.V, "Improving network performance and security in WSN using decentralized hypothesis testing "Journal of Chemical and Pharmaceutical Sciences(JCPS) Volume 9 Issue 2, April - June 2016 .

[34] Anuradha.C, Khanna.V, "A novel gsm based control for e-devices" Journal of Chemical and Pharmaceutical Sciences(JCPS) Volume 9 Issue 2, April - June 2016

[35] Anuradha.C, Khanna.V, "Secured privacy preserving sharing and data integration in mobile web environments " Journal of Chemical and Pharmaceutical Sciences(JCPS) Volume 9 Issue 2, April - June 2016

[36] Sundarraj, B., Kaliyamurthie, K.P. Social network analysis for decisive the ultimate classification from the ensemble to boost accuracy rates 2016 International Journal of Pharmacy and Technology

[37] Sundarraj, B., Kaliyamurthie, K.P. A content-based spam filtering approach victimisation artificial neural networks 2016 International Journal of Pharmacy and Technology83.

[38] Sundarraj, B., Kaliyamurthie, K.P. Remote sensing imaging for satellite image segmentation 2016 International Journal of Pharmacy and Technology8 3 .

[39] Sivaraman, K., Senthil, M. Intuitive driver proxy control using artificial intelligence 2016 International Journal of Pharmacy and Technology84.

[40] Sivaraman, K., Kaliyamurthie, K.P. Cloud computing in mobile technology 2016 Journal of Chemical and Pharmaceutical Sciences92.

[41] Sivaraman, K., Khanna, V. Implementation of an extension for browser to detect vulnerable elements on web pages and avoid click jacking 2016 Journal of Chemical and Pharmaceutical Sciences92

\section{AUTHORS PROFILE}

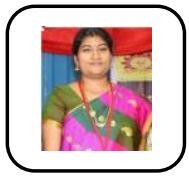

C.Anuradha, Assistant Professor, Department of Computer Science \& Engineering, Bharath Institute of Higher Education and Research, Chennai, India

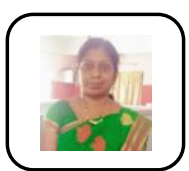

N.Priya, Assistant Professor, Department of Computer Science \& Engineering, Bharath Institute of Higher Education and Research, Chennai, India

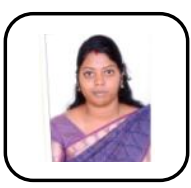

S. Sangeetha, Assistant Professor, Department of Computer Science \& Engineering, Bharath Institute of Higher Education and Research, Chennai, India

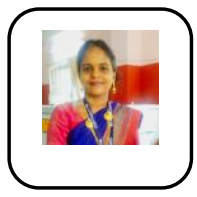

G. Kavitha, Assistant Professor, Department of Computer Science \& Engineering, Bharath Institute of Higher Education and Research, Chennai, India 